\title{
DISCERNMENT AND BIBLICAL SPIRITUALITY: AN OVERVIEW AND EVALUATION OF RECENT RESEARCH
}

\begin{abstract}
This article briefly and very generally explores some of the developments in the field of biblical spirituality over the past six decades by analysing and discussing some seminal publications on the theme of discernment. It begins the overview with the articles on discernment and discretion in the Dictionnaire de Spiritualite (1957) and then focuses on publications of the past twenty years. It discusses how discernment has moved beyond uncritically assumed dichotomies, beyond the separation of discernment and discretion, and the division between the Bible and philosophy. It also points out how recent publications emphasised for the first time the importance of communal discernment and thus overcame the untenable dualism between personal and communal discernment.
\end{abstract}

\section{INTRODUCTION}

This article aims to concisely and briefly analyse the field of discernment as it has been researched over the past six decades. This is especially needed, because no such research overview is available at present. In order to meet the need for such an overview, the article focuses on some of the major research works in the scientific forum during this period of time with regard to discernment, particularly as it was understood in the field of biblical spirituality. In doing so, it offers some suggestions about research trends within which future discussions on discernment could be conducted. Given the restricted space, only the most basic trends can be pointed out. ${ }^{1}$

1 This article was originally presented as an introductory paper to a conference on Discernment in Spirituality and Biblical Spirituality held in Malta in May

Prof. dr. Kees Waaijman, Professor Emeritus, Radboud University, Nijmegen and The Netherlands and Research Fellow, Department of New Testament, University of the Free State, Bloemfontein, 9300, South Africa. E-mail: Kees.Waaijman@ titusbrandsmainstituut.nl. 
Recent literature on discernment will be discussed by opening up the space between the two poles of an ellipse. The ellipse covers the six decades in which spirituality as a discipline developed extensively from a discipline that was studied within rather fixed boundaries to a vast field of research that can hardly be overseen.

One pole consists of the basic insights reflected in the third volume of the Dictionnaire de Spiritualite which appeared in 1957 at a time when such boundaries were set and clear. Consisting of 17 volumes with over 60000 pages written by more than 1500 contributors, this publication appeared from 1932 to 1995. Its full title is Dictionnaire de spiritualité. Ascétique et mystique. Doctrine et histoire. This encyclopaedia is a valuable point of departure, because it both offers a synthesis of the research on discernment available at that time and was influential in the subsequent period. An analysis of this material will expose the reader to a wide range of publications which appeared in the foregoing era.

The other pole is a bibliography of the monographs of the past twenty years with regard to discernment. This second pole will reflect literature published since 1990, which provides an insight into the present state of the art and a useful framework for an ongoing reflection on discernment, especially in terms of biblical spirituality. This overview of literature of the past two decades can only be cursory, as approximately 280 studies have been published. Any present discussion of discernment will benefit from such an overview.

\section{DISCERNMENT IN THE DICTIONNAIRE DE SPIRITUALITÉ}

The theme of discernment in the Dictionnaire de Spiritualité is developed in such a way that the materia tractanda is divided into two separate articles or lemmata. The first one, dealing with the discernment of the spirits (in Latin known as discretio spirituum), encompasses 70 columns. This first lemma was written by five specialists: Jacques Guillet (1957: 1222-1247) for the biblical period; Gustave Bardy (1957:1247-1254) for the time of the Patristics in east and west; Francois Vandenbroucke (1957:1254-1266) for the Middle Ages; Joseph Pegon (1957:1266-1281) for the modern period, and Henri Martin (1957:1281-1286) for systematic reflections and conclusions. The second article or lemma, discussing the virtue of

2012. The intention was to introduce the participants to the most recent publications in the field and to explain some implications for further reflection on discernment. It does not wish to be comprehensive or exhaustive. The format of that presentation is retained in this article. 
discretion (in Latin known as discretio), encompasses 19 columns. This second article was written by only one expert, André Cabassut (1957:13111330). These articles will now be discussed in terms of three issues.

\subsection{Splitting the theme}

One of the first questions that presents itself has to do with its form. It is an intriguing question as to why it was decided to split the field of discernment into two lemmata. In addition, it is also striking to note the imbalance in the number of columns allocated to the two sections. This also begs an explanation.

These questions could be answered on two levels. On the one hand, the article reflects the Jesuit background of the editors, who were Jesuits. In this tradition, there is a self-evident and decisive difference between discernment of the spirits and discretion as a virtue. They regarded Ignatius of Loyola as the champion of discernment of the spirits. This is clear by the extensive attention paid to him in this first article. The whole period of the modern discernment of the spirits is dominated in this article by the figure and works of Ignatius. Twelve of the fifteen columns are devoted to him and to Scaramelli, who was also a Jesuit. Major figures from this period are not even named or considered. This includes Teresa of Avila, John of the Cross, Vincent de Paul and Francois de Sales. It is, for example, equally striking that no attention was paid to Gerlach Peters, one of the main sources of Ignatius with regard to discernment. The second article in the encyclopaedia about discretio, the capacity to distinguish and the sense of moderation, starts with a discussion of Thomas Aquinas, who connected the traditional notion of discretio with the Aristotelian virtue of fronesis (prudence) as the mother and moderator of all virtues, as discretio was regarded since the times of the desert monks.

The question is whether this redactional decision to separate the two seminal motifs of discernment is tenable and whether there is such a fundamental difference between the two forms of discernment that the two separate articles can be justified. This is even more so, given that there is an enormous overlap in the two articles of spiritual writers. Both articles discuss authors such as Cassian, Augustin, Gregory the Great, Bernard, Richard of St. Victor, Thomas Aquinas, Catherine of Siena, Thomas a Kempis, and Ignatius himself. There are, obviously, differences between "discernment of the spirits" and "discretion", but there are also deep and inseparable connections. Whatever may be our position regarding the approach of the theme of diakrisis, it is important to take a critical stand concerning the dichotomy that was created between these two discernments in the encyclopaedia. 


\subsection{Splitting the background}

A second question that presents itself has to do more directly with the field of biblical spirituality. It is striking that the two lemmata are presented against different backgrounds. The discernment of the spirits starts with a great deal of biblical data from both the Old and the New Testament (Qumran included). The data is discussed in 25 columns. This is more than 30 per cent of the article. In the lemma discretio, on the other hand, only one column deals with the Bible. After some semantic remarks concerning the notion of discretio, it starts with a description of the philosophical background of this concept. This is done, first, in a discussion with Thomas Aquinas, who identified discretio with prudentia, the moderator of all virtues. After this opening paragraph, discernment is discussed in terms of Greek philosophy. It involves reflection on the notion of measure, moderation and harmony as the inner rule of conduct in all domains of human activities.

Once again, one could question whether these differences in background are tenable and are grounded in reality. "Discernment of the spirits" has 25 columns with a wealth of biblical material without any reference to the philosophical traditions, whereas "discretion" has only one column containing biblical information and five columns of philosophical discussions. Are there enough reasons for such a contrast?

\subsection{Individual and communal discernment}

A third question that presents itself concerns the subject and the object of the two forms of discernment in each of them. In both, "discernment of the spirits" and "discretion" are perceived as acts performed by an individual. This impression is confirmed by the fact that discernment is placed within the context of spiritual direction, conscience, personal experience, choice and feelings. The subject is challenged to examine and test the deeper motivations. Subject and object are similar in this article. It is about the human person, accompanied by a spiritual director.

Completely absent in this presentation - which has been strongly influenced by post-tridentine individualistic spirituality - is the communal dimension of discernment. This communal aspect is an essential feature in, for instance, the Collationes of Cassian, the Carmelite Rule, the practices of the Modern Devotion and the conferences of Vincent de Paul. A pertinent example can be found in the last words of the Carmelite Rule, "You are, however, to use discernment, which is the moderator of virtue" (Waaijman 1999:247-257). The Carmelites practised this discernment in the weekly chapter. It is in this chapter where "excesses and faults of the 
brothers, if such come to light, are to be corrected in the midst of love" (Waaijman 1999:131-136).

In discussions of discernment, one needs to consider a balance between the two extremes. There is, on the one hand, discernment for an individual by an individual, accompanied by an individual. There is, however, also a group discernment performed by the group for a person or for a group. From this point of view, the lack of a communal perspective on discernment in the encyclopaedia's article challenges contemporary researchers to re-conceptualise discernment.

\section{DISCERNMENT IN RESEARCH OF THE PAST TWENTY YEARS}

In a second part of this article, attention must be paid to the other pole of the ellipse, by discussing monographs on discernment which were published over the past twenty years. During this period, approximately 280 studies were published. This represents an average of 15 monographs annually. In this instance, one can specify three observations.

\subsection{The world of the spirits}

A first observation is how much research has been carried out over the past two decades concerning the world of the spirits. Many of the publications of this period can be grouped together because of their interest in this theme.

Some remarks are needed to explain why these publications are related bibliographically to the theme of "discernment of the spirits". Many scholars, who are not theologically interested in spirituality, regard the world of the spirits as an important field of experience. For them, this includes good spirits, evil spirits, angels and devils. Whereas, in the theology of spirituality, the spirits are mostly spiritualised into motivations or dynamics, the field of the spirits is concrete and almost material in anthropology. That is the reason why these studies of the world of the spirits are mostly done by anthropologists and sociologists. I counted 115 studies, almost fourty per cent of all monographs in the field of discernment of the spirits.

On the one hand, these publications describe the esoteric scene in terms of themes such as channelling, near-death experiences, voices, visions, demons and angels. From the perspective of higher spirituality and well-established schools of spirituality, this world of the spirits belongs to the so-called dark areas of spirituality. One does, however, find this 
shadowy empire in the artistic sphere of film, theatre, poetry and novels. Three titles provide good examples of this interest, the nature of research on them and the extent to which this research is being conducted. There is, first, the German publication with the telling title, Lexikon der Monster, Geister und Demonen. Die Geschöpfe der Nacht aus Mythos, Sage, Literatur und Film: Das (etwas) andere Who is who (Borrmann \& Borrmann 2001). In an English context, there is the equally comprehensive Spirits in culture, history, and mind (Mageo \& Howard 1996) and Rethinking ghosts in world religions (Poo 2009).

On the other hand, this shadowy side of modernity is mirrored by two other phenomena which form part of our culture. The first one concerns indigenous spiritualities. A significant number of monographs describe the world of spirits in indigenous spiritualities and in different cultural settings such as India, China, Thailand, Cambodia, Korea, Africa, Brazil, and so on. Paradigmatic is the more recent study of Cohen (2010), The mind possessed: The cognition of spirit possession in the Afro-Brazilian religious tradition. The other phenomenon is the world of the spirits in late medieval culture. In this instance, there is a large number of studies, among which there is a German title, Engel, Teufel und Dämonen. Einblicke in die Geisterwelt des Mittelalters (Herkommer e.a., 2006, Berner Mittelalter Zentrum). Two other studies focus on ghosts in medieval times. There is Medieval ghost stories. An anthology of miracles, marvels and prodigies (Joynes, 2001) and Ghosts in the Middle Ages: The living and the dead in medieval society (Schmitt \& Fagan, 1998).

This world of spirits is closely connected with the experiences of women in the Middle Ages. It is striking that some, especially from the perspective of the so-called higher spirituality, regard their experiences as belonging to the lower areas of spirituality and mysticism of those days. All these shadowy areas deal with experiences, imageries, voices and visions, perceived as representing the divine world. They have been judged in a mostly depreciating manner as lower experiences that are different from higher areas of spirituality, particularly from clerical spirituality, which developed certain techniques of discernment and claimed the grounds of the so-called higher spirituality.

This has implications for reflection on and research of spirituality, but also of discernment. Until recently, spirituality with its modern rationality failed to develop categories in order to understand the value of representations such as these that were so different from what interested researchers on spirituality until now. Authors took a judgmental attitude towartds these phenomena associated with the world of the spirits. They regarded themselves as the true judges who could relegate these 
phenomena to the so-called lower areas of spirituality. There is still a need to reflect on this issue in order to design categories of discernment that do not display the inquisitional attitude of judging and that do not depreciate lower forms of spirituality. It is spirituality of the marginals that deserves to be taken seriously and as phenomena in their own right.

\subsection{Ignatius and the others}

Reflection on discernment cannot ignore the prominent figure and place of Ignatius. The position of Ignatius of Loyola in the field of discernment is still very strong. This is made clear by the fact that, over the past twenty years, 28 monographs alone were dedicated to the Ignatian approach of discernment. This is significant, given that it represents ten per cent of the publications that appeared in this period.

It is striking, though, that Ignatius has been losing his dominant position in research on discernment. Gradually, other figures have been studied, as is reflected in monographs on discernment on Origen, Cassian, Benedict, Evagrius of Pontus, Bernard of Clairveaux, Clara of Assisi, Bridget of Sweden, Catharine of Siena, Gerson, Teresa of Avila, John of the Cross, Jonathan Edward, Pierre Favre, and others. Although the monographs on these authors do not match the 28 monographs in the Ignatian style, they make a significant contribution, because they opened up new perspectives. In doing so, they provide a new entry into the history of Christian spirituality.

In addition, it is noteworthy that the important theme of the origins of Christian discernment is now dealt with more adequately. In the time of the Dictionnaire, the entire Bible was analysed by one person only (Jacques Guillet). Over the past 20 years, nine monographs have been published, three of them more thematic in nature, the others focusing on texts. Various authors have now contributed with specialised studies on discernment.

The titles of the three thematic monographs reveal the more complex and specialised nature of the ongoing reflection on discernment. There is, first, a more general work on Authenticity: A biblical theology of discernment (Dubay 1997) and the Spanish work, Dos caminos: El discernimiento en Jesucristo (Randle 2003). Then there is a more focused work on Prophecy and discernment (Moberly 2006).

This thematic work is supplemented by six studies devoted to Biblical and Early Christian texts. The most encompassing study is the analysis by Elisabeth Hense, Frühchristliche Profilierungen der Spiritualität: Unterscheidung der Geister in ausgewählten Schriften: Didache, Erster Clemensbrief, Barnabasbrief, Hirt des Hermas, Erster Johannesbrief, De 
Principiis und Vita Antonii, in which she traces discernment in a wider range of early Christian texts. Other studies deal with New Testament writings (Paul and the Synoptics), whereas two texts from the New Testament received special attention: 1 John 4 and 1 Corinthians 12 and 14.

From this overview of publications on discernment over the past two decades, one major conclusion can be drawn regarding future research. The bibliographical data from this period indicates that a more balanced picture of the tradition of discernment is available than was the case in earlier times. This more informed picture is, however, restricted to the period since the New Testament times. It remains striking that research on discernment in the Old Testament is still mainly lacking. In fact, it is so striking that it appears that discernment does not exist in Old Testament Scripture. This indicates a major area of research that requires more attention.

\subsection{The community as subject and object of discernment}

A third observation concerns the communal dimension of discernment. It was pointed out how, for a long time, discernment was regarded as an individual matter. It was mostly associated with spiritual direction and the challenge to an individual to examine and test his/her deeper motivations. This initial approach changed to a very large extent. Approximately 50 monographs of the past 20 years deal with the communal dimension of discernment. This is a notable development, especially since this represents almost twenty per cent of the publications that were considered for this essay. When this is compared with the situation almost six decades ago and the point of departure in the Dictionnaire de Spiritualité, this is really a breakthrough.

There is a further pattern to be noted in these studies. Some of them are focused on the community as medium in quo the discernment is performed. In this regard, the following five titles are indicative of the trend in this research: Guidelines for communal discernment (Curtiss 2008); Group spiritual direction: Community for discernment (Dougherty 1995); Grounded in God. Listening hearts: Discernment for group deliberations (Farnham, 1999); Communal wisdom: A practical guide for group discernment (Gallagher \& Richardson, 2009), and Discerning God's will in community (Sparks, 2002). Such titles would have been inconceivable at the time of the Dictionnaire de Spiritualité. They further indicate that modern research on discernment is seeking a balance. This is confirmed by a publication by Martínez (2001), Discernimiento personal y communitario: 
Necessidad, claves, ejercicio, in which both personal and communal discernment is investigated.

Other studies on communal discernment, if not most of them, are related to processes of discernment in the church. In this instance, it is again notable how such studies are focused on discernment in Protestantism, particularly in reformed contexts. A good example of this trend is the work by Elfond (1999), We discern together: Group guidance in the Reformed tradition. In fact, in Protestantism in general, discernment has become an important issue. This happens, as the publications reveal, in faith communities of the Mennonites, the Quakers, the Lutheran Church, the Presbyterians, the Pentecostals, the Methodists and the Baptists.

The growing interest in discernment among Protestants, however, differs from group to group. Their interests vary. In some works, discernment is related to distinguishing truth and error. Once again the titles say it all: A call for discernment: Distinguishing truth from error in today's church (Adams 1998); Exposing witchcraft in the church (Godwin 1997), and God's trademarks: How to determine whether a message, ministry, or strategy is truly from God (Otis 2000). In these studies, the interest is oriented towards the difference between true and false. The basic feeling behind the need for discernment is that of uncertainty. In some instances, the notion of discernment is understood naively as being about judging. In this case, one could even sense an inquisition in waiting.

Other studies, however, reveal a distinctly more open attitude. In this instance, the interest is more hermeneutical, as the following titles reveal: Uncovering your church's hidden spirit (Hahn 2001); Discerning congregational identity and ministry (Howe 2002), and Equipping believers with a hermeneutical and theological foundation for exercising spiritual discernment (Langford 1994).

These publications reveal that they originated in times of transition. This awareness of living in such times is even reflected in a publication by Bassman entitled Discerning congregational calling in a time of rapid change (2007).

Finally, in these publications, discernment is understood as supporting the church in its reflection on the way forward and on its future. That discernment, which helps to discover the way of God in our time, is indicated in the study by Morris \& Olsen entitled Discerning God's will together: A spiritual practice for the church (2001). Discernment thus has practical implications - it is about the process of decision-making, as Ortiz (2000) argues in his Discernment: A theological process in ecclesial 
decision-making, and about Selecting church leaders: $A$ practice in spiritual discernment (Olsen \& Morseth 2002).

This pattern with its various aspects alerts one to the broad scope of discernment. It is not only individual and communal in nature; it also has different functions within a communal setting. Future research needs to be aware of the need to open up this broad scope on discernment more fully. It should avoid focusing on regarding discernment merely as separating good from evil or simply as judgement. By taking a fresh look at this phenomenon and having an openness to its complexities, one can read the signs of the times without the stress of anxiety.

\section{REFLECTION}

In this short reflection about recent publications, presented with broad strokes of the brush, almost too broad, it has become abundantly clear that there have been major developments in the reflection on discernment as a research topic. The brief and sketchy overview of the publications in the field over the past six decades confirms the large number of new perspectives that have been mooted. In many instances, simply noting the titles is already informative about these many perspectives.

This history challenges the researcher to continue thinking in a new way about discernment as a central issue in spirituality. More debate is, for example, needed about what discernment may be. More effort is needed to transcend some dichotomies which can no longer be seriously defended. This includes such dichotomies as separating discernment and discretion, the bible and philosophy, and the dichotomy between Ignatian and other traditions. In addition, the dualism of personal and communal ways of discernment, the uncritical schism between higher and lower forms of spirituality, and the opposition between judging and understanding are no longer tenable.

These dichotomies are not all differences "for the sake of heaven" and may well not endure. They may be useful to sharpen our sense for discernment. It could be that discernment opens up a hermeneutical dimension, thus helping to decipher complex situations and mixtures of power and freedom. Discernment is perhaps a process of listening and learning, seeking the golden mean which could establish itself in the midst of the spiritual community. Discernment may try to understand the way to God's destination, as Richard of Saint-Victor stated:

Discernment is knowing what is, in the light of what is possible from the perspective of God for whom nothing is impossible (Vandenbroucke 1957:1257). 
All these dimensions are needed in the ongoing reflection on discernment as a key issue in spirituality.

\section{BIBLIOGRAPHY}

AdAMS, J.

1998. A call for discernment: Distinguishing truth from error in today's church. Woodruff, SC: Timeless Texts.

BARDY, G.

1957. Discernement des esprits. II. Chez les pères. In: Dictionnaire de Spiritualité III (Paris: Beauchesne), cols. 1247-1254.

BASSMAN, J.

2007. Discerning congregational calling in a time of rapid change. Thesis (D Min). Pittsburgh Theological Seminary.

Borrmann, N. \& Borrmann, C.

2001. Lexikon der Monster, Geister und Dämonen : die Geschöpfe der Nacht aus Mythos, Sage, Literatur und Film : das (etwas) andere Who is who. Köln: Parkland.

Cabassut, A.

1957. Discrétion. In: Dictionnaire de Spiritualité III (Paris: Beauchesne), cols. 1311-1330.

COHEN, E.

2010. The mind possessed: The cognition of spirit possession in an AfroBrazilian religious tradition. Oxford: Oxford University Press.

Curtiss, V.

2008. Guidelines for communal discernment. Louisville, KY: Presbyterian Church U.S.A.

DOUGHERTY, R.

1995. Group spiritual direction: Community for discernment. New York: Paulist Press.

DuBAY, T.

1997. Authenticity: A biblical theology of discernment. San Francisco: Ignatius Press.

ELFOND, C.

1999. "We discern together: group guidance in the Reformed tradition". Thesis (D Min). Washington, DC: Wesley Theological Seminary.

Farnham, S., Hull, S. \& Mclean, R.

1999. Grounded in God: Listening hearts discernment for group deliberations. Harrisburg, PA: Morehouse Pub. 
GallagheR, B. \& RichaRdson, S.

2009. Communal wisdom: A practical guide for group discernment. Kensington, N.S.W.: Nelen Yubu Publications.

Godwin, R.

1997. Exposing witchcraft in the church. Orlando, FL: Creation House.

GuILLET, J.

1957. Discernement des esprits. I. Dans l'Ecriture. In: Dictionnaire de Spiritualité III (Paris: Beauchesne), cols. 1222-1247.

HaHN, C.

2001. Uncovering your church's hidden spirit. Bethesda, MD: Alban Institute.

Hense, E.

2010. Frühchristliche Profilierungen der Spiritualität : Unterscheidung der Geister in ausgewählten Schriften : Paulusbriefe, Didache, Erster Clemensbrief, Barnabasbrief, Hirt des Hermas, Erster Johannesbrief, De principiis und Vita Antonii. Berlin: Lit.

Herkommer, H., Schwinges, R. \& Pfaffen, M.-C.

2006. Engel, Teufel und Dämonen: Einblicke in die Geisterwelt des Mittelalters. Basel: Schwabe.

Howe, A.

2002. Discerning congregational identity and ministry. Thesis (D Min). Pittsburgh, PA: Pittsburgh Theological Seminary.

JOYNES, A.

2001. Medieval ghost stories: An anthology of miracles, marvels and prodigies. Woodbridge: The Boydell Press.

LANGFORD, A.

1994. Equipping believers with an hermeneutical and theological foundation for exercising spiritual discernment. Thesis (D Min). Fort Worth, TX: Southwestern Baptist Theological Seminary.

Mageo, J. \& Howard, A.

1996. Spirits in culture, history, and mind. New York, NY: Routledge.

MARTIN, $\mathrm{H}$.

1957. Discernement des esprits. V. Discernement des esprits et direction spirituelle. In: Dictionnaire de Spiritualité III (Paris: Beauchesne), cols. 1281-1286.

Martínez, M.

2001. Discernimiento personal y comunitario: necesidad, claves, ejercicio. Madrid: San Pablo.

MOBERLY, R.

2006. Prophecy and discernment. Cambridge Cambridge University Press. 
MorRis, D. \& Olsen, C.

2001. Discerning God's will together: A spiritual practice for the church. Bethesda, MD: Alban Publications.

Olsen, C. \& Morseth, E.

2002. Selecting church leaders: A practice in spiritual discernment. Bethesda, MD: The Alban Institute.

Ortiz, H.

2000. Discernment: A theological process in ecclesial decision making. Thesis (D Min). Decatur, GA: Columbia Theological Seminary.

OTIS, G.

2000. God's trademarks: How to determine whether a message, ministry, or strategy is truly from God. Grand Rapids, MI: Chosen Books.

Pegon, J.

1957. Discernement des esprits. IV. Période moderne. In: Dictionnaire de Spiritualité III (Paris: Beauchesne), cols. 1266-1281.

Poo, M.-C.

2009. Rethinking ghosts in world religions. Leiden: Brill.

RANDLE, G.

2003. Dos caminos: el discernimiento en Jesucristo. Buenos Aires: San Benito.

SchmitT, J.-C. \& FAGAN, T.

1998. Ghosts in the Middle Ages: The living and the dead in medieval society. Chicago: University of Chicago Press.

SPARKS, K.

2002. Discerning God's will in community. Thesis (D Min). Tulsa, OK: Phillips Theological Seminary.

VANDENBROUCKE, F.

1957. Discernement des esprits. III. Au moyen age. In: Dictionnaire de Spiritualité III (Paris: Beauchesne), cols. 1254-1266.

WAAIJMAN, K.

1999. The mystical space of Carmel: A commentary on the Carmelite rule. Leuven: Peeters. The fiery arrow collection 1.

Keywords

Spirituality

Biblical Spirituality

Discernment of Spirits
Trefwoorde

Spiritualiteit

Bybelse Spiritualiteit

Onderskeiding van die geeste 